\title{
INDIVIDUAL VARIATION BETWEEN TRANSLATORS IN THE USE OF CLAUSE BUILDING AND CLAUSE REDUCTION
}

\author{
HILDEGUNN DIRDAL \\ University of Oslo
}

\section{ABSTRACT}

\begin{abstract}
Recent years have seen an increasing interest in translators' voices as manifested in their writing style. The present study is an investigation of differences in the use of clause building and clause reduction, which has not so far been investigated in any depth with regard to individual variation. The findings show that translators have distinct styles both with respect to how closely they follow the source text and in the structures they prefer when they introduce changes. The study also demonstrates the importance of analysing changes in context, as translators may be forced to perform syntactic changes that are in principle optional because they have made certain choices in other places of the text. Finally, the study emphasizes the advantage of corpora comprising multiple translations of the same source text.
\end{abstract}

\section{[1] INTRODUCTION}

Translators often engage in clause building and reduction, moving between different levels, such as phrases and clauses, for a variety of reasons. Sometimes they are forced to make changes, for example when translating an English -ing clause into Norwegian, which does not have this type of clause. However, even in these cases translators usually have a choice when it comes to how to solve the problem. In this study, I was interested in looking at how variable the practise of clause building and reduction is and whether it is part of what might be called a translator's individual voice. This question may be divided into a quantitative and a more qualitative part: 1 ) do some translators engage in clause building and reduction more often than others, and 2) do they prefer different kinds of clause building/reduction?

Section [2] gives an introduction to the notions of voice and style in translation studies and explains how this investigation will add to previous research in the area. Section [3] defines the notions of clause building and clause reduction, and section [4] introduces the corpus used in the study, a corpus created specifically with the aim of studying individual variation between translators. The find- 
ings from the study are presented and discussed in section [5], with first a predominantly quantitative part focussing on overall numbers, before I take a closer look at clause building from coordinate clauses and from prepositional phrases.

\section{[2] THE VOICE AND THE STYLE OF A TRANSLATOR}

Recent years have seen an increased interest in VOICE in translation, the term being used about a variety of voices, from the physical voices of interpreters, dubbing actors/singers and actors/singers of translated songs and plays, to the metaphorical voices of authors, translators and interpreters, as well as narrators and characters in works of fiction (Alvstad 2013). This article will be concerned with an aspect of the translator's voice.

Translators often report listening to the voice of the author of an original and endeavouring to reproduce this voice in translation (Munday 2008, 17), and readers are usually meant to forget that they are reading a translation (Hermans 1996, 25ff.). Hermans talks about an "illusion of transparency and coincidence" we think we hear the author's voice when in fact it always comes to us through the translator's voice. The illusion may be broken in instances when the translator openly draws attention to the fact that the text is a translation, for example through the use of notes and brackets, or when the original contains linguistic self-referentiality that causes incongruities or contradictions in the translation, but most of the time the translator's voice remains hidden (Hermans 1996, 27ff.). That is, it is hidden from the reader approaching only the translated text. However, it can be brought into the light if the translation is compared to the original or to translations by other translators, as the translator's presence must manifest itself in the linguistic choices made in the creation of the text. I will follow Munday (2008) in considering style as the linguistic manifestation of the translator's voice:

Whereas we shall use voice to refer to the abstract concept of authorial, narratorial, or translatorial presence, we consider style to be the linguistic manifestation of that presence in the text. Since the text is the only immediately visible part of the narrative, it is only by studying the language of the text that the style of the author or translator might really be identified and hence the voice(s) present in the discourse be determined. Voice is therefore to be approached through style. (Munday 2008, 19)

Style is a matter of pattern and choice: writers choose between different options allowed by a language, and their choices come together in patterns of individual preferences (see e.g. Baker (2000, 245), Baker (2004, 29), Marco (2004, $74)$ and Munday $(2008,35))$. Baker $(2000,246)$ and Munday $(2008,34 f f$.$) argue$ 
that style needs to include patterns of both conscious and unconscious choices. Although a study of style can also encompass a study of the effect on the reader and the reasons for the writer's selections ((Malmkjær 2003, 38f. $)^{1}$, see also BoaseBeier (2006)), this article will be text-oriented, focussing mainly on whether it is possible to detect patterns in different translators' choices within one specific linguistic domain, namely that of clause building.

Several different linguistic items/structures have been studied in connection with individual translators' style, e.g., reporting structures (Baker 2000), sexist language and repetition of lexical phrases (Baker 2004), various modal expressions (Baker 2004; Bosseaux 2004; Winters 2009), deixis (Bosseaux 2004), transitivity patterns (Bosseaux 2004; Marco 2004), religious terminology (Malmkjær 2003), calquing (Marco 2004), contractions (Olohan 2003), split infinitives (Saldanha 2004), loan words and code-switches (Winters 2004), subject selection and sentence openings (Johansson 2007), and type/token ratios and average sentence length (Baker 2000; Johansson 2011). Munday's 2008 book-length study of Latin American writing covers many aspects, such as lexical richness, the use of slang and idiomatic phrases, noun phrase structure, calquing and more.

Studies of clause building, however, have tended to focus on what is common to translators as well as on cross-linguistic differences (e.g. Cosme (2006), Doherty (2004a,b), Fabricius-Hansen et al. (2005), Nordrum (2007), Solfjeld (1996, 2008)). Although they sometimes note that there is variation between translators, this is not something that is explored further. As far as I know, clause building has not been looked at in connection with individual translator style, apart from briefly in Johansson (2011), where ten translators are compared along a number of parameters: lexical variation, sentence division, clause building and reduction, subject selection and sentence opening. The paper focuses on overall statistics, however, and on giving some examples of the variation that is found. To take the parameter most relevant for the present study, namely clause building and reduction, Johansson gives the number of instances of clause building and reduction for each translator, offers a few examples to illustrate types of clause building, and discusses the ten different translations of one sentence from the corpus to show how widely the solutions may differ. He ends the section saying that clause building "deserves a much fuller treatment", but that this is beyond the scope of his paper (Johansson 2011, 10). In the present study, I will work towards a slightly fuller treatment, although it will be far from exhaustive.

[1] Malmkjær $(2003,38)$ uses the term stylistics for the study of the effect or creation of meaning in the reader and reserves the term style for patterns of linguistic choice as such. 
[3] CLAUSE BUILDING AND CLAUSE REDUCTION：OPERATIONALIZATION FOR THE STUDY

In this article, I adopt a broad definition of clause building. An independent main clause with all its obligatory constituents overtly spelled out is seen as the highest level on the scale of clause building. All changes moving towards this level are seen as clause building. I thus include not only the creation of clauses from words and phrases, but also the creation of finite clauses from non-finite ones, cases where elided subjects and verbs are made overt and cases where coordinated clauses are made independent. The translation of one clause into two (or more) clauses is obviously also seen as clause building. The opposite strategy is referred to as clause reduction. Figure 1 shows the changes considered as clause building, while examples (1) and (2) show instances of clause building and reduction, both taken from the same translator (T1). Example (1) shows an instance of clause building of the "phrase $\Rightarrow$ clause" type, more specifically from a prepositional phrase to an adverbial clause, and (2) showns an instance of clause reduction where two clauses (a main clause including an -ing clause) have been merged into one simple clause.

$$
\begin{gathered}
\text { Word/phrase } \Rightarrow \text { clause } \\
\text { Non-finite clause } \Rightarrow \text { finite clause } \\
\text { Coordinated predicate } \Rightarrow \text { coordinated clause (with subject) } \\
\text { Providing overt subjects or verbs in clauses with elision } \\
\text { Coordinated clause } \Rightarrow \text { independent clause } \\
\text { One clause } \Rightarrow \text { two or more clauses (clause splitting) }
\end{gathered}
$$

FIGURE 1: Clause building.

(1) She smiled a little, over her milk ...

T1: Hun smilte litt da hun drakk melken sin ...

Lit.: She smiled a-little when she drank the-milk her ...

(2) Raymond made rather a noise coming downstairs.

T1: Raymond kom ikke direkte stille ned trappen.

Lit.: Raymond came not directly quietly down the-staircase.

The scale I use is reminiscent of Lehmann's 1988 scale of sententiality and nominality with non-finite structures in the middle, where we find the progressive loss of a number of different features, for example modality and tense, when moving from a sentential structure to a nominal one. Solfjeld (1996) has used Lehmann's model to look at translation between Norwegian and German, finding that the Norwegian translations were more sentential than the German originals. 
As for the placement of coordinated predicates and coordinated full clauses as different levels on my scale, other researchers have also noted that coordinated predicates are closer to subordinate clauses. Engen (2002) argues that they resemble each other in sharing subjects with the first coordinated clause (in the case of coordinated predicates) or the matrix clause (in the case of subordinate clauses), and Cosme (2006) shows that the distinction affects the likelihood of a coordinated clause being rendered as a subordinated one in translation between English and French. Although two clauses bound together by coordination are technically both coordinate clauses, I will be referring to the second clause as the coordinate clause. It is the second clause that is seen as less independent and that commonly lacks a subject. The first clause will be seen as equal to an independent clause and classified as such. Further, it is the presence of a coordinating conjunction that is taken as a sign of coordination, not punctuation. A sentence starting with a coordinating conjunction after a full stop will thus be classified as a coordinate clause, whereas two full clauses separated only by a comma will both be classified as independent clauses.

There are many interesting clause reorganizations which are not covered by the definition above, and of which there are also many in the corpus. These include changes from one type of non-finite clause to another (for example from an -ing clause to an infinitive clause) or one type of finite structure to another (for example from an SV(A) sentence to an existential).

The introduction of catenatives in translation, as in example (3), might look like translation of one clause into two, a finite clause and a subordinate non-finite one. However, since the catenative verb (begynte 'began') has auxiliary-like properties, such translation is regarded as a change within the verb phrase only, and not as clause building. The same can be said for pseudo-coordination, as in example (4), which has a function similar to catenatives (Quirk et al. 1985, 978), and of regular coordination of verbs or verb phrases (i.e. without other clause constituents).

(3) It would clear, the young men assured him, once the filtration was working again.

T1: De unge mennene forsikret ham at det ville klarne når filtreringen begynte å fungere igjen. [Lit.: started to work]

(4) It made vigorous thrusts with its hind legs, and vanished into the skimmer, from the mouth of which it peered out at Bernard.

T7: Den sparket kraftig fra med bakbena og forsvant inn i skumfilteret der den satt og tittet ut på Bernard. [Lit.: sat and peered]

T1: Frosken sparket kraftig fra med bakbena og forsvant inn bak overløpsristen, hvor den ble sittende og titte ut på Bernard. [Lit.: remained sitting and peered] 


\section{[4] CORPUS AND METHOD}

When studying translators' individual styles, we need to compare different translators. Previous studies have used both text collections of various sizes that have been searched manually and electronically searchable corpora of different kinds. Electronic corpora may contain only translated texts in a certain language (and be used in comparison with a comparable corpus of texts in the same language that are not translations), they may also contain the source texts for the translations, and they may in addition have comparable texts translated in the opposite direction. In all cases, the corpora contain texts by different translators, but these are usually translations of different source texts. Thus, if the individual translators are compared, it is difficult to say whether differences are due to the translators' preferences or to the nature of the texts. Retranslations of the same work have also been studied, but there is usually considerable time between different translations of the same source text, which means that both language usage and translation ideals may have changed, in addition to the complication of a later translation possibly building on or reacting to a previous one. Ideally, we would want to keep all other variables constant, and compare different translations of the same texts created at the same time and under as similar conditions as possible. Only then can we be certain that the differences found are due to the translators' individual styles. It has sometimes happened that the same work has indeed been translated by different translators simultaneously, (although in some cases previous translations exist, and it is not known to what degree the translators have used them). Winters $(2004,2009)$ was able to compare two different German translations of Fitzgerald's The Beautiful and the Damned, both published in 1998; Bosseaux's 2004 corpus contains two French translations of Woolf's To the Lighthouse published within just three years of each other; and May's 1994 collection of English translations of Russian fiction contains four separate translations of Solzhenitsyn's Odin den' Ivana Denisovicha [One Day in the Life of Ivan Denisovich], all from 1963.

Seeing the need for a more controlled study of individual differences in the context of English-Norwegian translation, Stig Johansson and Linn Øverås created a unique corpus, consisting of one fictional and one non-fictional text and ten different translations of each (the English-Norwegian Multiple-Translation Corpus). The fictional text amounts to about 6,000 words. The non-fictional text is longer, but for the sake of comparability, the translators were only asked to translate the first 6,000 words. They were remunerated according to existing rates. All the translators were experienced; the ones asked to translate the fictional text had received prestigious prizes for their work. As Johansson remarks, "The great advantage of the multiple-translation material ... is that the translations have been produced independently by professional translators working under conditions which were as similar as possible, including the time of the task" 
(Johansson 2011, 17). The texts chosen were fairly recent and none of them had been translated before.

There are few studies that have used this corpus to look at individual variation. Two notable exceptions, however, are Johansson (2007), which treats subject selection and sentence openers in detail, and Johansson (2011), described above (section [2]). (See also the contributions by Behrens (this volume) and Elsness (this volume).)

For this study, I used only the fictional text, which is the short story "A Lamia in the Cevennes" by Byatt (1996). ${ }^{2}$ I compared the original and the translations manually to identify cases of clause building and reduction and coded these for type - what kind of entity they originated from and what sort of entity resulted. The instances were sorted with the help of the concordancer AntConc (version 3.2.4w, Anthony 2011). Some of the changes were then investigated in more detail to look for qualitative differences.

\section{[5] DIFFERENCES BETWEEN THE TRANSLATORS}

Table 1 shows the overall number of instances of clause building and reduction found in the ten translations in the corpus. Just like Johansson (2011), I will use T1, $\mathrm{T} 2$, etc. to refer to the different translators. Johansson used a narrower definition of clause building and reduction than me, and our numbers can therefore not be directly compared, but the trends are the same.

TABLE 1: Instances of clause building and reduction for each translator.

\begin{tabular}{lrrrrrrrrrr} 
& T1 & T2 & T3 & T4 & T5 & T6 & T7 & T8 & T9 & T10 \\
\hline Clause building & 126 & 76 & 74 & 113 & 86 & 158 & 90 & 125 & 93 & 83 \\
Clause reduction & 57 & 30 & 38 & 37 & 35 & 84 & 32 & 48 & 34 & 45 \\
\hline
\end{tabular}

We see quite substantial quantitative differences between the translators, with instances of clause building ranging from 74 (T3) to 158 (T6) and instances of clause reduction from 30 (T2) to 84 (T6). T2 and T3 have the lowest numbers of clause building (76 and 74 respectively) and are also at the lower end of the spectrum when it comes to clause reduction (30 and 38), whereas T6 seems to be particularly fond of both processes (158 and 84).

We can also note that there is more building than reduction. This might be part of the general trend of explicitation that has been noted in translation, since going from a non-finite to a finite clause, providing subjects, etc. means that more information is spelled out. However, turning coordinate clauses into independent

[2] The short story contains ten lines from a poem by Keats. These lines and their renderings in the translations have been kept out of the analysis for two main reasons: firstly, different considerations come into play in the translation of poetry, and, secondly, not all the translators have translated these lines into Norwegian. 
ones might be said to be the opposite of explicitation (i.e. implicitation), since it involves the loss of a coordinator and therefore might also involve a loss of an explicit marker of the relationship between two clauses (unless this relationship is marked in some other way, by e.g. an adverbial). And indeed the trend is for more insertion than omission of coordinating conjunctions overall, although not for all the translators.

There are different attempts at accounting for the tendency for translations to have more explicitation than implicitation. The explicitation hypothesis, first formulated by Blum-Kulka (1986) says that there is an increase in explicitness from a source text to a target text independent of the linguistic systems involved and attributable to the process of translation itself (see also Klaudy (2001)). Becher (2011, 27f.) argues that the explicitation hypothesis as it stands is unmotivated, unparsimonious and vaguely formulated, and that the asymmetry hypothesis is to be preferred. Klaudy (2009) intends the asymmetry hypothesis as a further development of the explicitation hypothesis. It says that there will always be more explicitation going from language $\mathrm{X}$ to language $\mathrm{Y}$ than there will be implicitations in translation from language $Y$ to language $X$. This is because translators prefer to explicitate if they have a choice, whereas they often do not implicitate even if it is possible (i.e. the hypothesis pertains to optional operations). Such an asymmetry can be explained by general pragmatic and psychological processes - translators wish to ensure understanding across cultures (Klaudy 2009) and to avoid the risk of getting complaints from target readers and losing clients (Becher 2011).

Unfortunately, a proper discussion of these hypotheses is outside the scope of this article. First of all, it would necessitate a further analysis of the data to ascertain whether other elements express the meaning that was carried by the omitted elements, and also whether there are meaning elements that have been left out in other places when we have clause building. We would also have to count in how many cases clause building or reduction is actually possible, and in what portion of these instances the translators have availed themselves of these opportunities. Secondly, we cannot find out whether the differences between building and reduction in the Norwegian data is due to translation-specific processes or differences between Norwegian and English unless we compare with a set of translations going in the other direction (Norwegian-English). A corpus with Norwegian-English translations comparable to the ones analysed here is unfortunately not available at present.

What we can say, however, is that the use of clause building and reduction varies a great deal from translator to translator, and thus may be said to be a part of their individual style. Not only do they use both processes to varying degrees, the ratio between building and reduction varies too, from 1.8 cases of clause build- 
ing for each case of clause reduction for T10 to 3.1 cases of clause building for each case of clause reduction for $\mathrm{T} 4$.

However, comparing numbers can be deceptive with as broad a definition of clause building and reduction as the one outlined above. For example, a reduction of two sentences to a phrase can hardly be compared to a reduction of an independent main clause to a coordinate clause. It is thus important to look more closely at the types of changes found for each translator. We can begin by looking at the starting points for the clause building, indicated in Table 2:

TABLE 2: Starting points for clause building.

\begin{tabular}{|c|c|c|c|c|c|c|c|c|c|c|}
\hline & $\mathrm{T} 1$ & $\mathrm{~T} 2$ & T3 & $\mathrm{T} 4$ & $\mathrm{~T} 5$ & T6 & $\mathrm{T} 7$ & $\mathrm{~T} 8$ & T9 & $\mathrm{T} 10$ \\
\hline Main clause & 12 & 5 & 4 & 14 & 4 & 22 & 7 & 20 & 5 & 9 \\
\hline Adverbial clause & 1 & 2 & & & 1 & 7 & 1 & 1 & & \\
\hline Relative clause & 5 & 2 & & 7 & 2 & 3 & 2 & 2 & & \\
\hline That clause & & & 1 & 1 & & & & & & \\
\hline Infinitive clause & 17 & 5 & 6 & 10 & 10 & 10 & 8 & 10 & 6 & 11 \\
\hline -ing clause & 33 & 29 & 30 & 37 & 30 & 35 & 30 & 33 & 35 & 33 \\
\hline Past participle clause & 5 & 3 & 2 & 2 & 5 & 3 & 3 & 3 & 6 & 2 \\
\hline Verbless clause & 2 & & & 4 & 1 & & 4 & 3 & 3 & 2 \\
\hline Adverb phrase & & & & & & & & 1 & & 1 \\
\hline Adverb phrase with infinitive clause & 1 & & & & & & & & & \\
\hline Adjective phrase & 4 & 3 & 2 & 1 & 2 & 1 & 3 & 1 & 2 & \\
\hline Noun phrase & 11 & 9 & 5 & 7 & 7 & 11 & 7 & 9 & 9 & 8 \\
\hline Prepositional phrase & 11 & 3 & 8 & 8 & 8 & 24 & 10 & 18 & 12 & 2 \\
\hline Prep. phrase with -ing clause & 1 & 1 & & 1 & 1 & 3 & 1 & 1 & 1 & \\
\hline Prep. phrase with relative clause & & & & & & & & 1 & & \\
\hline Adjective & 2 & 2 & 1 & 3 & 3 & 2 & & 1 & & 1 \\
\hline Adverb & & 1 & 1 & & & & & 2 & & 1 \\
\hline Noun & 3 & & & 1 & 1 & 3 & 1 & 3 & 1 & 1 \\
\hline Determiner & & 1 & & 1 & & & & & 1 & 2 \\
\hline Interjection & & & & & & & & 1 & 1 & \\
\hline Clause splitting/ reorganization & 14 & 8 & 13 & 16 & 10 & 26 & 11 & 14 & 10 & 8 \\
\hline$\varnothing$ & 4 & 1 & 1 & & 1 & 8 & 2 & 1 & & 2 \\
\hline Other & & 1 & & & & & & & 1 & \\
\hline TOTAL & 126 & 76 & 74 & 113 & 86 & 158 & 90 & 125 & 93 & 83 \\
\hline
\end{tabular}

We find a wide range of starting points from main clauses to nothing $(\varnothing)$, with different types of finite clauses, non-finite clauses, phrases and words in between. At first glance, it might look as if there are no obvious qualitative differences, but that the translators all build from a variety of sources, some just more often than others. And with some types it is difficult to draw conclusions because the numbers are low.

However, if we look closely, it is possible to detect some more qualitative differences. In the following, I have chosen to focus on clause building starting with main clauses and prepositional phrases. These are represented by a fair number of instances, and main clauses and prepositional phrases are categories that are 
present in both Norwegian and English. Thus the translators are not in theory forced to make changes, as they are with -ing clauses.

\section{[5.1] Clause building from main clauses}

Clause building from main clauses involves the upgrading of coordinate clauses to independent ones, as well as insertion of overt subject and verbs in coordinate or independent clauses. Table 3 shows how often the different translators made use of these types of clause building.

TABLE 3: Clause building starting from main clauses.

\begin{tabular}{|c|c|c|c|c|c|c|c|c|c|c|}
\hline & $\mathrm{T} 1$ & $\mathrm{~T} 2$ & T3 & $\mathrm{T} 4$ & T5 & T6 & $\mathrm{T} 7$ & $\mathrm{~T} 8$ & T9 & $\mathrm{T} 10$ \\
\hline Coordinate to independent & 4 & 2 & 1 & 7 & 1 & 16 & 2 & 10 & & 5 \\
\hline Supplying elided constit. in indep. clauses & 1 & 1 & 1 & 1 & & 2 & 1 & 2 & 1 & \\
\hline Supplying subjects in coordinate clauses & 5 & 2 & 2 & 5 & 2 & 3 & 1 & 6 & 2 & 3 \\
\hline $\begin{array}{l}\text { Supplying elided verbs in coordinate clauses } \\
\text { Supplying both subjects and other }\end{array}$ & & & & 1 & & & & & & \\
\hline elided constituents in coordinate clauses & 2 & & & & 1 & 1 & 3 & 2 & 2 & 1 \\
\hline TOTAL & 12 & 5 & 4 & 14 & 4 & 22 & 7 & 20 & 5 & 9 \\
\hline
\end{tabular}

When it comes to changing a coordinate clause into an independent one, this basically amounts to omitting a coordinating conjunction. (See section [3] on operationalization above.) Some translators in particular do not seem to like to start a sentence with a coordinating conjunction. In the original story, there are nine sentences starting with And after a full stop. T6 has decided to omit six of these coordinators, T3 and T9 keep them all, whereas the rest omit one or two each. It is especially when several sentences in a row start with coordinators that a number of translators have elected to omit one of them. This is illustrated in example (5). Note that both of the clauses in the example are classified as coordinated clauses, since they start with coordinators. The first clause is coordinated to the previous sentence, not shown in the example.

(5) And against the green hump the blue sky was one blue, and against the bald stone another ...

T1: Og mot den grønne haugen hadde den blå himmelen én blåfarve, og mot den nakne steinen en annen...

T2: Mot den grønne kulen hadde himmelen én blåtone, og mot den nakne steinen en annen... [first coordinator omitted]

T3: Og sett mot den grønne pukkelen var den blå himmelen av én slags blåfarge, mot den nakne steinen av en annen... [second coordinator omitted] T4: Mot den grønne pukkelen hadde den blå himmelen én blåfarge, og mot den nakne steinen en annen... [first coordinator omitted]

T5: Mot den grønne kollen var den blå himmelen én slags blå, og mot det nakne berget en annen... [first coordinator omitted] 
T6: Mot den grønne pukkelen hadde den blå himmelen én blåfarve, mot den nakne steinen en annen... [both coordinators omitted]

T7: Og mot den grønne pukkelen hadde den blå himmelen én blå farge, og mot den nakne steinen hadde den en annen...

T8: Mot den grønne såten antok himmelen en blåfarge, og mot den nakne steinen en annen... [first coordinator omitted]

T9: Og mot den grønne kollen hadde den blå himmelen én blåtone, og mot den nakne steinen en annen...

T10: Og mot den grønne åsen var den blå himmelen en type blått, og mot de nakne klippene en annen...

But, on the other hand, is usually rendered as Men. There are nine sentences starting with But, and only in two cases have translators chosen a rendering without a coordinator. These are shown in examples (6) and (7).

(6) But the surface could be a reflective plane, with the trees hanging in it, with two white diagonals where the aluminium steps entered.

T2: Overflaten kunne også være et speil med trærne på hodet, to hvite diagonaler der aluminiumstrappen gikk ned.

Lit.: The-surface could also be a mirror with the-trees on the-head, two white diagonals where the-aluminium-staircase went down.

(7) But you must have faith in me.

T6: Du må bare ha tiltro til meg.

Lit.: You must only have faith to me.

In both cases we see that other words keep some of the linking or adversative function of But, namely også ('also') and bare ('only'). Nome (2013, 111f.) also found that adversative connectors were less frequently omitted in translation between French and Norwegian (in both directions). She suggests this is because it is comparatively more difficult for a reader to reach the correct interpretation of the relationship between the clauses if adversative connectives are not present (Nome 2013, 229ff.; 241).

Coordinate conjunctions following a comma are also sometimes omitted. This is seen as a change into an independent clause, no matter whether the comma is kept or changed to a full stop. If the clause has no overt subject, it will have to be supplied. The translators who make most of these changes are also among those who had more omissions when the conjunction was at the beginning of a sentence. T4, T6 and T8 have five, nine and seven respectively. (T8 has also changed a coordinated clause starting with while into an independent clause). All of these had two or more omissions of And after a full stop. Again, we also see the tendency of omission being used more often when there are several coordinate conjunctions following each other in the original, as in example (8), or when there would be 
several in the translation because of other changes, such as an infinitive clause being translated into a coordinated clause, illustrated in example (9).

(8) Finally he slept, and in the morning his world was awash with river-water, and the heart-beat machine was still howling on the river-bank, boumboum, boum-boum.

T4: Omsider la han seg til å sove. Om morgenen var hele hans verden overskylt av elvevann, mens hjerteslagmaskinen fortsatt hylte nede ved elvebredden, bom-bom, bom-bom.

Lit.: Eventually laid he himself to to sleep. In the-morning was whole his world awash by river-water, while the-heart-beat-machine still howled down by the-river-bank, bom-bom, bom-bom.

T6: Omsider sovnet han, og da morgenen kom, var hele hans verden oversvømmet. Hjerteslagsmaskinen dunket fremdeles sine bom-bom, bom-bom langs elvebredden, ...

Lit.: Eventually fell-asleep he, and when the-morning came, was whole his world awash. The-heart-beat-machine beat still its bom-bom, bom-bom along the-river-bank, ...

(9) They went to bed, and Bernard woke once in the night to realise he had not shut his bedroom window as he usually did; a shutter was banging.

T6: De gikk og la seg. Utpå natten våknet Bernard av en skodde som sto og slo, og skjønte han måtte ha glemt å lukke vinduet på soveværelset.

Lit.: They went and laid themselves. Into the-night woke Bernard of a shutter which stood and hit, and understood he must have forgotten to close the-window on the-bedroom.

T8: De gikk til sengs. Bernard våknet en gang i løpet av natten og oppdaget at han ikke hadde lukket soveromsvinduet, hvilket han alltid gjorde; en vinduslem stod og slo.

Lit.: They went to bed. Bernard woke one time in the-course of the-night and discovered that he not had closed the-bedroom-window, which he always did; a shutter stood and hit.

There is an old prescriptive rule saying that you should not start a sentence with a coordinating conjunction (see e.g. Vinje $(1998,101)$, who condemns the rule). Perhaps some translators are more influenced by this rule than others, to the extent that they deviate from the use of conjunctions in the original even when the original violates a similar prescriptive rule in the source language. A special effect is often created by the violation of such rules, in this case of a certain overuse of simple conjunctions. Omitting them would mean that the effect is not retained to the same degree. 
So far, we have seen that $\mathrm{T} 4, \mathrm{~T} 6$ and $\mathrm{T} 8$ are the translators who omit conjunctions the most. T10 also omits the coordinating conjunction a number of times: once when it appears after a full stop in the original and four times after a comma. However, many of these do not seem to be simple omissions. Two of them are linked to more substantial changes (see examples (10) and (11)), and in one case the interpretation of the clause in question is not straightforward, which leads to quite different solutions by the individual translators (12).

(10) Bernard spread his arms and legs and floated.

T10: Bernard fløt urørlig med armer og bein bredt ut fra kroppen.

Lit.: Bernard floated motionless with arms and legs spread out from thebody.

(11) 'And we'll be off after breakfast and leave you to your painting,' said Raymond.

T10: 'Vel, vi stikker nå etter frokost. Vi skal ikke ta opp mer av din dyrebare tid,' sa Raymond.

Lit.: 'Well, we go now after breakfast. We shall not take up more of your precious time,' said Raymond.

(12) It was a lovely colour, a natural colour, a colour that harmonised with the hills, and it was not the problem Bernard was preoccupied with.

T1: ... og det var ikke det problemet som bekymret Bernard.

Lit.: ... and it was not the/that problem which worried Bernard.

T2: ... så den var ikke problemet som opptok Bernard.

Lit.: ... so it was not the-problem which occupied Bernard.

T3: ... og det var ikke problemet som Bernard var opptatt av.

Lit.: ... and it was not the-problem which Bernard was occupied of.

T4: ... og opptok ham ikke som noe problem.

Lit.: ... and occupied him not as any problem.

T5: ... og ikke det problemet som opptok Bernard.

Lit.: ... and not the problem which occupied Bernard.

T6: ... og ikke var noen del av det problemet Bernard var opptatt av.

Lit.: ... and not was any part of the problem Bernard was occupied of.

T7: ... og det var ikke det problemet som opptok Bernard.

Lit.: ... and it was not the/that problem which occupied Bernard.

T8: ... men det var ikke det problemet Bernard var opptatt av.

Lit.: ... but it was not the/that problem Bernard was occupied of.

T9: ... men dét var ikke problemet som opptok Bernard.

Lit.: ... but that was not the-problem which occupied Bernard.

T10: ... det var ikke det problemet som opptok Bernard.

Lit.: ... it was not the/that problem which occupied Bernard. 
When it comes to spelling out elided constituents in independent clauses, the numbers are very low, and all the instances come from the three sentences in (13), (14) and (15). Example (13) has a type of elision that does not exist in Norwegian (of main verb + object). The translators are therefore forced to make changes. Some fill in the elided constituents, but others try to find other possible replies that would perhaps be just as idiomatic or likely in Norwegian.

(13) 'I don't,' said Bernard.

T1: 'Nei om jeg gjør,' sa Bernard. [Lit.: No if I do]

T2: 'Det gjør jeg ikke,' sa Bernard. [Lit.: That/it do I not]

T3: 'Det burde jeg ikke,' sa Bernard. [Lit.: That/it should I not]

T4: 'Det gjør jeg aldeles ikke,' sa Bernard. [Lit.: That/it do I certainly not]

T5: 'Nei,' sa Bernard. [Lit.: No]

T6: 'Ikke jeg, nei,' sa Bernard. [Lit.: Not I, no]

T7: 'Nei da,' sa Bernard. [Lit.: No then]

T8: 'Det gjør jeg ikke,' sa Bernard. [Lit.: That/it do I not]

T9: 'Det gjør jeg ikke,' sa Bernard. [Lit.: That/it do I not]

T10: 'På ingen måte,' sa Bernard. [Lit.: In no way] ${ }^{3}$

In the other two cases, the same type of elision is possible in Norwegian, and has indeed been used by most of the translators. It is perhaps significant that two of the four translators who have supplied elided constituents are also among those who changed coordinated clauses into independent clauses most often.

(14) Brought my own provisions.

T1: Jeg har med litt niste. [Lit.: I have with some provisions.]

T2: Tok med mine egne forsyninger. [Lit.: Took with my own supplies.]

T3: Tok med meg litt proviant. [Lit.: Took with me some provisions.]

T4: Tok like godt med meg noe proviant. [Lit.: Took as well with me some provisions.]

T5: Har med egne forsyninger. [Lit.: Have with own supplies.]

T6: Jeg holder råvarene. [Lit.: I hold (=supply) the-raw-materials.]

T7: Jeg tok med egne forsyninger. [Lit.: I took with own supplies.]

T8: Jeg har med meg egne forsyninger. [Lit.: I have with me own supplies.]

T9: Tok med egen proviant. [Lit.: Took with own provisions.]

T10: Tok med noen forsyninger. [Took with some supplies.]

(15) 'You don't want river-water,' said Raymond Potter. 'What about liverflukes and things, and bilharzia?'

T6: 'Du må da ikke ta vann fra elven,' sa Raymond Potter. 'Har du ikke hørt om leverikter og den slags, og bilharziose?'

[3] The different quotation marks used by the translators have been standardized. 
Lit.: 'You must then not take water from the-river,' said Raymond Potter. 'Have you not heard about liver-flukes and that sort, and bilharzia?'

Compared to elision in independent clauses, the original contains more cases of coordinated clauses without subjects (or coordinated predicates). Again, the translators supply subjects to varying degrees. However, it is not always simply a question of adding a subject. There seem to be four distinct categories: Firstly, there are a few cases where some of the translators have chosen så ('so') instead of og ('and') as a coordinating conjunction. ${ }^{4}$ This forces them to use an overt subject. Secondly, there are cases where the coordinated clause contains an adverbial in initial position, and if the adverbial is to be kept there, the Norwegian clause also needs the subject to be spelt out. Thirdly, a subject might be added in the coordinated clause because the previous clause has been changed so that the subjects of the two clauses no longer refer to the same entity. It is thus only a subset of the cases that are simple and optional additions of a subject.

With regard to the first category, it is impossible to see any clear patterns, partly because there are only two sentences from the original that only a few translators have rendered using så instead of og. An example from T3 is shown in (16). T4 and T8 have chosen similar solutions. In the other sentence, it is T1 and $\mathrm{T} 2$ that have chosen renderings with så.

(16) He did not know how he would take to solitude, and laid in a large quantity of red wine ...

T3: Han var ikke sikker på hvordan han ville holde ut ensomheten, så han kjøpte inn store mengder rødvin ...

Lit.: He was not sure on how he would hold out the-loneliness, so he bought in large amounts red-wine ...

The second category is found in the translations of four different sentences from the original that have coordinated clauses with initial adverbials and without subjects, one of them shown in example (17). The translators use a variety of solutions, sometimes keeping the adverbial in initial position and adding a subject,

[4] Norsk referansegrammatikk (Faarlund et al. 1997, 1116; 1139ff.) lists så as a coordinating conjunction and classifies it as a causal one together with for. The clause with så expresses a consequence of what is expressed in the clause before it. They note that main clauses with så are close to subordinate clauses with så, which express a purpose. The word order differs in the two types of clauses. Quirk et al. (1985, 927f.) call English so a conjunct. They set up a scale with central coordinators (and and or) at the top and subordinators (if and because) at the bottom and show that conjucts belong in the middle, sharing some featurs with both. However, they note that but is closer to the conjucts than the central coordinators are, and that yet, so, neither and nor are more coordinator-like than the typical conjuncts such as however. Since they have some of the typical features of coordinators, Quirk et al. suggest that they may be called semi-coordinators. It would probably be possible to set up a gradient scale for Norwegian co- and subordinators too. One of the features that distinguishes så from the most central coordinators (og and eller) is the impossibility of subject elision in the clause it introduces (Faarlund et al. 1997, 1143). 
sometimes changing the position of the adverbial and sometimes omitting the adverbial. The coordinated clause is also occasionally rendered as a subordinate or independent clause. Although most translators have a variety of solutions, T1 stands out as the one who most clearly favours the solution of keeping the initial adverbial and adding a subject ( 3 out of 4 times), whereas T3, T5 and T7 tend to change the position of the adverbial (3 out of 4 times).

(17) One day he got up as usual and as usual flung himself naked into the water to watch the dawn in the sky and the blue come out of the black and grey in the water.

T1: En dag sto han opp som vanlig, og som vanlig kastet han seg naken i vannet for å se solen stige opp på himmelen og blåfarven tre frem fra det grå og sorte i vannet.

Lit.: One day stood he up as usual, and as usual threw he himself naked in the-water for to see the-sun rise up on the-sky and the-blue-colour tread forwards from the grey and black in the-water.

T3: En dag sto han opp som vanlig og hev seg som vanlig naken ut $i$ vannet for å observere demringen på himmelen og det blå oppstå av vannets svarte og grå.

Lit.: One day stood he up as usual and threw himself as usual naked out in the-water for to observe the-dawn on the-sky and the blue rise of thewater's black and grey.

T6 is the translator who has the greatest range of solutions and the most substantial changes, once changing the position of the adverbial, once turning the coordinated clause into an adverbial clause, once into an infinitive clause and once into an independent clause.

TABLE 4: Different solutions in the rendering of seven coordinate clauses without subjects.

\begin{tabular}{|c|c|c|c|c|c|c|c|c|c|c|}
\hline & $\mathrm{T} 1$ & $\mathrm{~T} 2$ & T3 & $\mathrm{T} 4$ & T5 & T6 & $\mathrm{T} 7$ & $\mathrm{~T} 8$ & T9 & $\mathrm{T} 10$ \\
\hline Optional addition of subject & & & & 4 & & 1 & & 1 & 1 & 2 \\
\hline $\begin{array}{l}\text { Addition of subject because the subject } \\
\text { of the previous clause is changed }\end{array}$ & 1 & 1 & & & 1 & 1 & 1 & 2 & & \\
\hline $\begin{array}{l}\text { Coordinate clause changed to finite } \\
\text { subordinate clause }\end{array}$ & 1 & & 1 & & 1 & & & 1 & 1 & \\
\hline $\begin{array}{l}\text { Coordinate clause changed to } \\
\text { independent clause }\end{array}$ & & & & & & 1 & & 1 & & \\
\hline Clause combination & 1 & & & & & & & & & \\
\hline No changes to coordination or subject & 4 & 6 & 6 & 3 & 5 & 4 & 6 & 2 & 5 & 5 \\
\hline
\end{tabular}

The third and fourth categories of changes are found in the translation of seven different sentences from the original. As we can see from Table 4, T4 stands out as the only translator who simply adds a subject in the coordinated clause 
more than half the time ( 4 times). T2, T3 and T7 are the most conservative, and $\mathrm{T} 1, \mathrm{~T} 6$ and $\mathrm{T} 8$ have the most variety in their changes.

So far, we have seen that $\mathrm{T} 2, \mathrm{~T} 3, \mathrm{~T} 5$ and $\mathrm{T} 7$ are the most conservative translators when it comes to the changes investigated. They seldom change a coordinated clause to an independent one, they never add an optional subject, and only once each have they added a subject in a coordinated clause because they have changed the previous clause. T4, T6 and T8 are the translators who make more changes. They often change a coordinated clause into an independent one. However, T4 is more prone to adding optional subjects, whereas T6 and T8 have more variety in their changes. T1 and T10 seem to be in an intermediate position so far. This is clearest from the number of coordinated clauses turned into independent ones. However, these cases are usually more complex for T10, where they seem to be linked to more comprehensive changes.

\section{[5.2] Clause building from prepositional phrases}

Looking at the clause building from prepositional phrases, we also see a few qualitative differences in addition to the quantitative ones. As Table 5 shows, only four translators (T1, T4, T6 and T8) sometimes turn prepositional phrases into independent or coordinated main clauses (two, one, five and four times respectively). T6 and T8 are the translators who most often build from prepositional phrases (27 and 20 times respectively), and also the ones with the widest range of endpoints for the process. The two of them seem similar in many respects, except for T6 making changes into relative clauses more often than adverbial clauses, and $\mathrm{T} 8$ the opposite. T2 and T10 are the most conservative, with hardly any clause building from prepositional phrases.

TABLE 5: Clause building from prepositional phrases.

\begin{tabular}{lrrrrrrrrrr} 
& T1 & T2 & T3 & T4 & T5 & T6 & T7 & T8 & T9 & T10 \\
\hline Independent clause & 2 & & & & & 4 & & 3 & & \\
Coordinate clause & & & & 1 & & 1 & & 1 & & \\
Adverbial clause & 4 & & 2 & 3 & 2 & 5 & 3 & 7 & 2 & 1 \\
$\begin{array}{l}\text { Relative clause } \\
\text { That clause }\end{array}$ & 4 & 2 & 4 & 3 & 3 & 7 & 5 & 4 & 9 & \\
Infinitive clause & 1 & 1 & 1 & 1 & 1 & 2 & 1 & 1 & & 1 \\
Past participle clause & & & 1 & & 1 & 2 & 1 & 1 & 1 & \\
Other & 1 & 1 & & 1 & 2 & 6 & 1 & 2 & 1 & \\
\hline TOTAL & 12 & 4 & 8 & 9 & 9 & 27 & 11 & 20 & 13 & 2 \\
\hline
\end{tabular}

There are no instances where all the translators have made the same change. In only one case could a prepositional phrase definitely not be used in Norwegian, 
and even then the translators have chosen different solutions, some rendering it as a genitive noun, some as a relative clause and one as an adverb phrase.

I decided to look more closely at the two translators who most rarely build clauses from prepositional phrases and the two who most frequently do so, to see how similar or different they are. To do this, I extracted all the prepositional phrases that have lead to clause building by at least one translator and looked at what these four have done in each case. There were $45 \mathrm{such}$ prepositional phrases in all.

Comparing $\mathrm{T} 2$ and $\mathrm{T} 10$, I found that they have each made structural changes 10 times out of 45 . In five cases, only $\mathrm{T} 2$ has made structural changes, in five other cases, only T10, and in the remaining five cases, both of them. Structural changes such as using a noun phrase, a noun or an adjective instead of the prepositional phrase are more frequent than clause building. However, T2 usually keeps closer to the original word for word, even when both of them keep the prepositional phrase structure. Some examples are shown in (18).

...with a French acceptance of Bernard's desperation.

T2: ...med fransk aksept av Bernards desperasjon.

Lit.: ...with French acceptance of Bernard's desperation

T10: ...med fransk intuitiv forståelse for Bernards desperasjon.

Lit.: ...with French intuitive understanding for Bernard's desperation.

(19) ...he had never gone along with Keats about all that stuff.

T2: ...hadde han aldri vært enig med Keats $i$ alt det der.

Lit.: ...had he never been agreeing with Keats in all that there.

T10: ...hadde han aldri kunnet følge Keats helt ut $i$ disse betraktningene.

Lit.: ...had he never could follow Keats completely out in these reflections.

(20) She smiled a little, over her milk

T2: Hun smilte litt over melken sin

Lit.: She smiled a-little over the-milk her

T10: Hun smilte litt, over melkeglasset

Lit.: She smiled a-little, over the-milk-glass

The differences between T2 and T10 thus seem to be greater on the lexical than the syntactic level. This is supported by the findings in Johansson (2011). T2 has the lowest number of both word tokens and types of all the translators, and also the lowest number of translator-unique types, whereas T10 is somewhere in the middle when it comes to word tokens, has the third highest number of word types and the highest number of translator-unique types.

Now let us turn to the translators that most often build clauses out of prepositional phrases. T6 has made structural changes (including clause building) to 29 out of the 45 prepositional phrases, and T8 to 18 of them. Only in 11 cases have 
they both made changes, and only 4 of them were of the same type. We can thus conclude that there is much individual variation between the two, but beyond that, clear patterns are difficult to detect, apart from the fact already noted that $\mathrm{T} 8$ seems to have a slight preference for adverbial clauses. T6, on the other hand, seems to use main clauses slightly more often than $\mathrm{T} 8$, since we find that the three independent main clauses produced by $\mathrm{T} 8 \mathrm{come}$ from the same string of prepositional phrases (see example (21)), whereas the four produced by T6 appear in different sentences.

(21) Swimming was a strenuous battle with immense problems, of geometry, of chemistry, of apprehension, of style, of other colours.

T6: Å svømme var anstrengende - en kamp med enorme problemer; det dreide seg om geometri, om kjemi, om erkjennelse, om stil, om andre farver.

Lit.: To swim was strenuous - a fight with enormous problems; it revolved itself about geometry, about chemistry, about realization, about style, about other colours.

T8: Svømmeturene bød på et utmattende basketak med umåtelig store oppgaver som måtte løses; det gjaldt geometri, det gjaldt kjemi, det gjaldt indre forståelse, stil, andre farger.

Lit.: The-swimming-trips offered on an exhausting scrimmage with extremely large tasks that must be-solved; it concerned geometry, it concerned chemistry, it concerned inner understanding, style, other colours.

In Section [5.1], T4, T6 and T8 were found to be similar in that they engage in clause building from main clauses more often than the rest. T4, however, is the only one who often just inserts an optional subject in a coordinated clause, whereas $\mathrm{T} 6$ and $\mathrm{T} 8$ show a greater variety of changes. In this section, we have seen that $\mathrm{T} 4$ is different from the other two also in having fewer instances of clause building from prepositional phrases. $\mathrm{T} 6$ and $\mathrm{T} 8$ are the translators who engage most often in this type of clause building, but there are differences even between these two. T8 might have a slight preference for using adverbial clauses, whereas T6 has an even larger number of clauses built from prepositional phrases than $\mathrm{T} 8$ and builds main clauses more often.

With respect to building from main clauses, T10 did not necessarily seem to be among the most conservative. However, he/she is the translator who most seldom builds clauses from prepositional phrases. When comparing with $\mathrm{T} 2$, who has also got very few clauses built from prepositional phrases, we see that the main difference between them is lexical rather than structural. 


\section{[6] CONCLUSION}

On the basis of overall numbers of clause building and reduction shown in tables 1 and 2, it might be tempting to conclude that the individual variation between translators is due to a weaker or stronger tendency to keep close to the source text, i.e. that they vary with respect to how free their translation is. T2 and T6 seem to be extremes in this regard, T2 following the original very closely and T6 translating rather freely. However, although different preferences for a close or free rendering of the text may be part of a translator's style, it cannot be the whole story. This is shown clearly in the comparison of two of the translators with the fewest instances of clause building, namely T2 and T10. Although both of them retain prepositional phrases to the same degree, they are very different with respect to lexis. Thus, although none of them might be said to be very free when it comes to syntactic structure, they are on opposite ends of the scale when it comes to lexical creativity. A comparison of some of the translators that are freer with respect to clause building also reveals differences, showing that even if translators are quite similar with respect to the number of changes they introduce, they may differ in the types of structures they prefer. We may therefore conclude that translators' styles include both the degree to which they introduce syntactic changes and the types of structures they prefer.

The findings also raise questions about the classification of certain syntactic changes as optional or obligatory. The changes we have looked at are in principle optional, in the sense that coordination and prepositional phrases exist in both English and Norwegian, and do not force a translator to render them using other syntactic means. However, when looking more closely at the changes, we see that many of them are motivated by lexical choices, diverging interpretations or changes in other places in the text, for example the choice of sa 'so' instead of og ('and') or the choice to keep an adverbial in initial position forcing the translator to insert a subject in a coordinate clause. This illustrates the interconnectedness of lexical and syntactic choices. It also shows that not only a freer rendering in one place, but also keeping close to the source text (by for example keeping adverbial position) may force the translator to make changes in other places. Statistics gleaned from corpus searches therefore need to be interpreted in the light of close investigations of context.

Finally, I hope that the investigation has shown the advantage of a corpus specifically designed to investigate individual differences between translators. When as many variables as possible are kept constant we can be more confident that the differences detected are indeed results of translators' individual styles and manifestations of their own voices in the translation. The corpus investigated also has drawbacks, however, most importantly the size (only 6,000 words from each translator) and the lack of a comparable set of translations in the opposite direction (Norwegian-English). I therefore want to end my article with a 
call for the compilation of more multiple-translation corpora of a similar type as a complement to existing translation corpora.

\section{CORPUS}

The Multiple-Translation Corpus (1997-1999), Dept. of British and American Studies, University of Oslo (http://www.hf .uio.no/ilos/tjenester/kunnskap/ sprak/omc/enpc/multtrans .html). Compiled by Linn Øverås and Stig Johansson in connection with the English-Norwegian Parallel Corpus.

\section{SOFTWARE}

Anthony, L. 2011. AntConc (version 3.2.4w) [computer software]. Tokyo, Japan: Waseda University. Available at: http://www.antlab.sci.waseda.ac.jp/

\section{REFERENCES}

Alvstad, C. 2013. Voices in translation. In Y. Gambier \& L. van Doorslaer (eds.), Handbook of Translation Studies, 207-210. Amsterdam: John Benjamins.

Baker, M. 2000. Towards a methodology for investigating the style of a literary translator. Target 12(2). 241-266.

Baker, M. 2004. The treatment of variation in corpus-based translation studies. In K. Aijmer \& H. Hasselgård (eds.), Translation and Corpora: Selected Papers from the Göteborg-Oslo Symposium 18-19 October 2003, 7-17. Göteborg: Acta Universitatis Gothoburgensis.

Becher, V. 2011. When and shy do translators add connectives? A corpus-based study. Target 23(1). 26-47.

Behrens, B. this volume. Nominalization: A Case Study of Linguistic text conventions in comparable and parallel texts: English and Norwegian. In S. O. Ebeling, A. Grønn, K. R. Hauge \& D. Santos (eds.), Corpus-based Studies in Contrastive Linguistics, vol. 6(1) Oslo Studies in Language, University of Oslo.

Blum-Kulka, S. 1986. Shifts of cohesion and coherence in translation. In J. House \& S. Blum-Kulka (eds.), Interlingual and Intercultural Communication: Discourse and Cognition in Translation and Second Language Acquisition Studies, 17-35. Tübingen: Narr.

Boase-Beier, J. 2006. Stylistic Approaches to Translation. Manchester and Kinderhook: St. Jerome.

Bosseaux, C. 2004. Translating point of view: A corpus-based study. Language Matters: Studies in the Languages of Africa 35(1). 259-274. 
Byatt, A.S. 1996. A lamia in the Cevennes. In C. Hope \& P. Porter (eds.), New Writing, vol. 5, 1-17. Vintage, in association with The British Council.

Cosme, C. 2006. Clause combining across languages: A corpus-based study of English-French. Languages in Contrast 6(1). 71-108.

Doherty, M. 2004a. Reorganizing dependences. SPRIKreports, reports of the project Languages in Contrast (Språk i kontast) .

Doherty, M. 2004b. Strategy of incremental parsimony. SPRIKreports, reports of the project Languages in Contrast (Språk i kontast) .

Elsness, J. this volume. Clausal modifiers in noun phrases: A comparison of English and Norwegian based on the Oslo Multilingual Corpus. In S. O. Ebeling, A. Grønn, K. R. Hauge \& D. Santos (eds.), Corpus-based Studies in Contrastive Linguistics, vol. 6(1) Oslo Studies in Language, University of Oslo.

Engen, J. H. 2002. 'Og' isn't always 'and': From coordination to subordination in English translations of Norwegian texts. University of Oslo MA thesis.

Faarlund, J.T., S. Lie \& K.I. Vannebo. 1997. Norsk referansegrammatikk. Oslo: Universitetsforlaget.

Fabricius-Hansen, C., W. Ramm, K. Solfjeld \& B. Behrens. 2005. Coordination, discourse relations, and information packaging - cross-linguistic differences. Paper presented at the Symposium on the Exploration and Modelling of Meaning (SEM), 14-15 November 2005.

Hermans, T. 1996. The translator's voice in translated narrative. Target 8(1). 23-48.

Johansson, S. 2007. Seeing Through Multilingual corpora: On the Use of Corpora in Contrastive Studies. Amsterdam: John Benjamins.

Johansson, S. 2011. Between Scylla and Charybdis: On individual variation in translation. Languages in Contrast 11(1). 3-19.

Klaudy, K. 2001. Explicitation. In M. Baker (ed.), Routledge Encyclopedia of Translation Studies, 80-84. London and New York: Routledge.

Klaudy, K. 2009. The asymmetry hypothesis in translation research. In R. Dimitriu \& M. Shlesinger (eds.), Translators and Their Readers: In Homage to Eugene A. Nida, 283-303. Brussels: Editions du Hazard.

Lehmann, C. 1988. Towards a typology of clause linkage. In J. Haiman \& S.A. Thompson (eds.), Clause Combining in Grammar and Discourse, 181-225. Amsterdam and Philadelphia: Benjamins. 
Malmkjær, K. 2003. What happened to God and the angels: An exercise in translational stylistics. Target 15(1). 37-58.

Marco, J. 2004. Translating style and styles of translating: Henry James and Edgar Allan Poe in Catalan. Language and Literature 13(1). 73-90.

May, R. 1994. The Translator in the Text: On Reading Russian Literature in English. Evanston, IL: Northwestern University Press.

Munday, J. 2008. Style and Ideology in Translation: Latin American Writing in English. New York and London: Routledge.

Nome, A. 2013. Connectives in Translation: Explicitation and Relevance: University of Oslo dissertation.

Nordrum, L. 2007. English lexical nominalizations in a Norwegian-Swedish contrastive perspective: Göteborg University dissertation.

Olohan, M. 2003. How frequent are the contractions? A study of contracted forms in the Translational English Corpus. Target 15(1). 59-89.

Quirk, R., S. Greenbaum, G. Leech \& J. Svartvik. 1985. A Comprehensive Grammar of the English Language. London: Longman.

Saldanha, G. 2004. Accounting for the exception to the norm: Split infinitives in translated English. Language Matters: Studies in the Languages of Africa 35(1). 39-53.

Solfjeld, K. 1996. Sententiality and translation strategies: German-Norwegian. Linguistics 34(3). 567-590.

Solfjeld, K. 2008. Sentence splitting and discourse structure in translations. Languages in Contrast 8(1). 21-46.

Vinje, F.-E. 1998. Bedre norsk: språkråd fra A til Å. Bergen: Fagbokforlaget.

Winters, M. 2004. F. Scott Fitzgerald's Die Schönen und Verdammten: A corpusbased study of loan words and code switches as features of translators' style. Language Matters: Studies in the Languages of Africa 35(1). 248-258.

Winters, M. 2009. Modal particles explained: How modal particles creep into translations and reveal transators' styles. Target 21(1). 74-97. 
AUTHOR CONTACT INFORMATION

Hildegunn Dirdal

Department of Literature, Area Studies and European Languages

University of Oslo

Norway

hildegunn.dirdal@ilos.uio.no 